$10-1-2011$

\title{
Electric Power Transmission And Distribution Equipment
}

\author{
David A, Petina \\ The Freedonia Group \\ Michael Murphy \\ The Freedonia Group \\ Andrew C. Gross \\ Cleveland State University, a.gross@csuohio.edu
}

Follow this and additional works at: https://engagedscholarship.csuohio.edu/bus_facpub

Part of the Marketing Commons

How does access to this work benefit you? Let us know!

Publisher's Statement

The final publication is available at Springer via http://dx.doi.org/10.1057/be.2011.22

\section{Original Published Citation}

Petina, D.A., Murphy, M., \& Gross, A.C. (2011). Electric power transmission and distribution equipment. Business Economics, 46(4), 249-259. doi:10.1057/be.2011.22

This Article is brought to you for free and open access by the Monte Ahuja College of Business at EngagedScholarship@CSU. It has been accepted for inclusion in Business Faculty Publications by an authorized administrator of EngagedScholarship@CSU. For more information, please contact library.es@csuohio.edu. 
Focus on Industries and Markets

\section{Electric Power Transmission and Distribution Equipment}

\author{
David A. Petina, Michael \\ Murphy, and Andrew C. Gross*
}

The U.S. electrical grid must be upgraded, and there is a strong debate about the characteristics of the next-generation electrical network. However, slow growth of electricity usage, among other factors, means that the demand for transmission and distribution (T\&D) equipment is growing slowly also. Within the T\&D equipment sector, switchgear and transformers are still the dominant segments, but sales of meters are growing rapidly in response to increased demands for security, safety, and connectivity. Six firms hold about 40 percent of the $T \& D$ equipment market share, selling to electric utilities, nonutility industrial firms, commercial firms, and residential customers. Foreign trade is also important in this industry, with the United States running a substantial trade deficit.
Keywords: electric power, transmission \& distribution $(T \& D)$ equipment, electricity demand and supply, product lines, end users, industry structure, U.S. market

he U.S. electrical grid is in dire need of upgrading, but as is the case with infrastructure in general, the process is slow. Beyond the debate over energy sources for generating power, there is also a strong debate about the development of the next-generation electrical transmission and distribution (T\&D) network.

In this paper, we analyze the U.S. market for electric T\&D equipment. Electric energy in the current macro setting is discussed first, followed by a brief look at electricity supply and demand. Key regulations and technical developments that pose both restraints and opportunities are profiled. This is followed by a discussion of $T \& D$ equipment supply in terms of major product lines and T\&D equipment demand by major end-use sectors. Then a specific sector, the commercial market, is highlighted. We conclude with an analysis of industry structure, marketing, collaboration, and merger activities.

\section{Electric Power and the Macro Environment}

Modern economies run on electricity; about one-third of the world energy is used for electric power. In the United States, electricity is integral and indispensable for homes, factories, and all types of commercial establishments. Any interruption in the steady supply of electric power is unwanted and can result in much economic loss. The nation's electric grid is a complex network of generation plants, transmission lines, and distribution systems. The North American grid consists of three major networks (Eastern, Western, and Texas) with 200,000 miles of high voltage transmission lines $(110 \mathrm{kv}$ to $765 \mathrm{kv}$ ) and million miles of distribution lines.

The federal government is currently pushing policies to upgrade the nation's aging electrical network. In mid-June 2011, Secretary of Energy Steven Chu called for a speed-up in the development of the nextgeneration electrical network 
[Vastag 2011]. This so-called smart grid would deliver power more efficiently, coordinate traditional and renewable sources, reduce consumption, and alleviate the number and length of outages. T\&D equipment should then be able to respond immediately to demand, yet maintain an instant response system to connectivity and other operating variables. At present, the nation's current electric grid is so creaky, according to $\mathrm{Chu}$, that "Edison would feel at home with most of today's power system." Per U.S. Department of Energy (DoE) figures, there were 349 blackouts in $2005-2009$ vs. 149 in 2000-2004.

According to the article just cited, the new policies immediately drew skepticism, in part because the Electric Power Research Institute (EPRI), an independent institute funded by the electric utility industry, estimates the cost of implementation to be in the $\$ 338$ to $\$ 476$ billion range. Nonetheless, the federal government is determined to push the electric power companies to invest in new technologies, provide loans to upgrade the transmission lines in rural areas, and fund "smart grid" R\&D activities from a DoE research hub. According to Dr. Chu, the technology underpinning the current U.S. electrical grid lags behind that of other countries, including China and Ireland. Their systems have more efficient high-voltage transmission lines, up-to-date distribution equipment, and better integration of power generation from traditional and renewable sources.

If the administration's policies are implemented, they would provide a major boost to T\&D investment. However, the fate of enabling legislation is highly uncertain.

The supply and demand situation for electric power T\&D equipment is clearly affected by both cyclical and secular macroeconomic variables. The most notable influence was the recent recession and ongoing slow recovery, causing slower spending patterns by households, business, and governments. The overall weakening in the economy has forced business firms to shelve major expansion plans through 2013. A significant share of $T \& D$ equipment demand is related to fixed investment activity. Both electric utilities and other industrial-commercial users are slowing down their purchases of switchgear, transformers, and other types of equipment.

\section{Electric Power (Electricity) Supply and Demand ${ }^{1}$}

Before electric power is transmitted and distributed, it must be generated at conventional dedicated power plants, cogeneration facilities, or at such natural/renewable facilities as hydro dams, geothermal heat sources, solar farms, or wind turbines. The generation of electricity is forecast to climb at less than 1 percent per year to 4.3 trillion kilowatt-hours in 2013. This pace reflects the growing demand for electricity services being offset by efficiency gains from new appliance standards and investments in energy-efficient end-use equipment [U.S. Energy Information Administration 2011]. Increases

\footnotetext{
${ }^{1}$ For methodology used in this study, see Deneen and Gross [2006], specifically p. 73: "Appendix: A Note on Methodology.”
}

in the efficiency of T\&D equipment have also contributed to the slowing pace.

For much of the 20th century, electricity came from regulated electric power utilities and specifically from their dedicated power plants that use coal, nuclear fission, and natural gas. Such utilities remain the largest generators of electricity at nearly half of the total output. Coal remains the dominant fuel at about half of utility generation. Still, the so-called independent power producers (IPPs) or non-utility generators (NUGs) have been more aggressive in constructing new generating capacity. These include cogeneration units that provide power and steam or other process heat for on-site use. Together IPPs are likely to provide almost half the nation's electricity by 2018. In Table 1, we show details on electric power generation by type of fuel and by type of industrial or generator facility. It is notable that while there is much publicity about renewable sources of electricity, these will provide only 14 to 17 percent of total output during 2013-2018.

Although the focus of this article (as well as the underlying 320-page report by The Freedonia Group on which it is based) is on T\&D equipment, we should note that spending for power generating equipment is also significant. In 2008, a total of $\$ 36$ billion was spent on all types of electric power equipment; of this sum turbines and generators accounted for $\$ 12$ billion, T\&D equipment for $\$ 21$ billion, and power wire/cable for $\$ 3$ billion. The three categories combined-constituting two percent of nonresidential fixed investment in 2008-will 


\begin{tabular}{|c|c|c|c|c|c|}
\hline \multirow[b]{2}{*}{ Item } & \multirow[b]{2}{*}{2003} & \multirow[b]{2}{*}{2008} & \multirow[b]{2}{*}{2013} & \multicolumn{2}{|c|}{ Annual growth } \\
\hline & & & & $08 / 03$ & $13 / 08$ \\
\hline Electricity by Type of Fuel & 3883 & 4105 & 4260 & $1.1 \%$ & $0.7 \%$ \\
\hline Coal & 1974 & 1990 & 2070 & 0.1 & 0.8 \\
\hline Gas & 666 & 890 & 720 & 6.0 & 4.3 \\
\hline Nuclear & 764 & 805 & 820 & 2.2 & 0.4 \\
\hline Oil & 119 & 45 & 50 & -18.0 & 2.2 \\
\hline Renewable/Other & 360 & 375 & 600 & 0.8 & 9.9 \\
\hline Electricity by Industrial Facility & 3883 & 4105 & 4260 & $1.1 \%$ & $0.7 \%$ \\
\hline Dedicated electricity ${ }^{\mathrm{a}}$ & 3525 & 3785 & 3915 & 1.4 & 0.7 \\
\hline Electric utilities & 2462 & 2470 & 2360 & 0.1 & -0.9 \\
\hline Indep. power producers & 1063 & 1315 & 1555 & 4.3 & 3.4 \\
\hline Cogeneration $^{\mathrm{b}}$ & 358 & 320 & 345 & -2.2 & 1.5 \\
\hline Electric power & 196 & 175 & 185 & -2.3 & 1.1 \\
\hline Other & 162 & 145 & 160 & -2.2 & 2.0 \\
\hline \multicolumn{6}{|c|}{$\begin{array}{l}\text { Independent power producers are industrial firms and/or non-utility generators who came into existence after deregulation in the } \\
\text { 1990s. } \\
\text { 'Cogeneration is the simultaneous production of electric power and heat in industrial plants. They may generate it directly or as } \\
\text { a byproduct (latter listed as "other" above). Such generation is usually for on-site use, however, in some cases it may be sold to } \\
\text { outsiders. }\end{array}$} \\
\hline
\end{tabular}

rise to $\$ 42.5$ billion in 2013 and to $\$ 50.7$ billion by 2018 . Within this total, turbines and generators are slated to rise at a 4.1 percent annual increase, compared with $\mathrm{T} \& \mathrm{D}$ equipment at a 2.6 percent annual pace and wires/cables at 5.1 percent per year during 2008-2013.

Demand for electricity increased more rapidly than GDP through 1960-1980 due to expanding production by end-users as well as new applications. The pace slowed slightly during 1980-2000, and then usage decreased and will continue to grow slowly in the present decade. The deceleration of demand is due largely to greater energy efficiency in end-use applications; price-induced and environment-related conservation by users; and specific legislation. Yet another factor is cogenera- tion in which industrial customers utilize heat from waste products rather than using electricity.

The use of electric power by major sectors of the U.S. economy is shown in Table 2.

The so-called retail sales break into three categories: residential at 35 , commercial also at 35 , and industrial at 30 percent of the total in 2008. These proportions show little or no change during the coming years. The nonretail category, called direct use, shows a fast increase, albeit from a small base. This occurs where a facility generates electricity onsite and then uses that power directly or transfers it to a co-located facility. Such consumption, including cogeneration, is slated to rise 2.7 percent annually compared with only 0.6 percent for retail sales.
In addition to increasing the efficiency of energy use in their production facilities, cogenerators may help to ensure a steady power supply to critical equipment, avoiding the threat of outages.

\section{Regulations and Standards}

Government regulations, industry standards, building codes, and a host of similar rulemaking procedures affect the generation, transmission, and distribution of electricity as well as its use and application. The most visible impact has been on the electric utility industry; the changing regulatory climate altered both the manner of power generation and how equipment suppliers position themselves. In brief, since the passing of the Public Utilities Regulatory 


\begin{tabular}{|c|c|c|c|c|c|}
\hline \multirow[b]{2}{*}{ Item } & \multirow[b]{2}{*}{2003} & \multirow[b]{2}{*}{2008} & \multirow[b]{2}{*}{2013} & \multicolumn{2}{|c|}{ Annual growth } \\
\hline & & & & $08 / 03$ & $13 / 08$ \\
\hline Electricity Generation & 3883 & 4105 & 4260 & $1.1 \%$ & $0.7 \%$ \\
\hline Less net losses \& exports & 221 & 225 & 240 & 0.0 & 0.3 \\
\hline Electricity Demand by End Users & 3662 & 3880 & 4020 & 1.1 & 0.7 \\
\hline Retail sales & 3494 & 3740 & 3860 & 1.4 & 0.6 \\
\hline Residential & 1276 & 1390 & 1390 & 1.7 & 0.0 \\
\hline Industrial & 1012 & 975 & 995 & -2.8 & 0.4 \\
\hline Commercial & 1206 & 1375 & 1475 & 2.3 & 1.4 \\
\hline Direct use ${ }^{\mathrm{a}}$ & 168 & 140 & 160 & -3.7 & 2.7 \\
\hline
\end{tabular}

Policies Act in 1978, electricity generation has shifted away from utilities and toward industrial firms and NUGs. Utilities have preferred equipment suitable for large, low-cost central stations, whereas NUGs tend to use equipment suitable for units with relatively low generating capacity. Competition encouraged by deregulation and cogeneration and renewable energy technologies derived from environmental concerns have increased. The result has been that generation has become much less centralized, making T\&D more complex, contributing to emergence of the idea of the smart grid.

Producers of T\&D equipment always had to comply with government regulations and industry standards. In the past, the focus of such rules and practices has been on safety and reliability. Now, other aspects have arisen as well: efficiency, environmental impact, access, compatibility, and connectivity. One key policy promulgated is that providers of electricity should vary their rates according to the costs that they incur, charging lower rates when relatively inexpensive base-load capacity is sufficient to meet demand and higher rates when expensive peak-load capacity must be brought on line. A related topic is to maintain system reliability even at times of high demand. Thus, it is not surprising that measurement is crucial and that meters are showing the fastest rate of growth in T\&D equipment. This means that metering programs will be a key component to developing a smart grid with an emphasis on advanced monitoring. This trend is accelerated by "distributed generation," in which individual customers, say residences with roof-top photovoltaic generation, are enabled by regulation to sell power back to the grid.

The makers of T\&D equipment have been negatively affected by the consolidation in the electric power utility industry that ensued after deregulation. Conversely, they benefited from the emergence of new, nonutility providers. At this time, the utilities are striving to enhance their relationships with large power users and allow them to purchase electricity in bulk. Such bulk purchases often require additional equipment, such as more switchgear and transformers. Other opportunities will come from the continuing penetration of renewable energy sources, the use of more circuit breakers for protection, and monitoring to improve connections, system stability, and reliability. Distributed generation and subsequent net metering programs require smart meters that can measure electricity flow both to and from the grid.

There are additional rules, standards, and practices that affect the installation and use of T\&D equipment. These range from federal and foreign (nonU.S.) rules to state and local regulations. The U.S. Environmental Protection Agency has long singled out sulfur hexafluoride for strict scrutiny. This compound is used in circuit breakers, switchgear, and other T\&D equipment for insulating, interrupting, and quenching 
capabilities, but it is also a potent greenhouse gas. Earlier, the European Union promulgated rules about use of various substances (lead, cadmium, and so on) used in T\&D equipment. There has also been concern with old transmission lines being pushed beyond their design limits.

\section{Technology-New Ideas, Innovative Products}

The long lifespan of electric power T\&D equipment has meant less pressure on providers to seek new ideas and products. The electric utility sector is in a mature stage, spending less than 0.5 percent of its revenue on R\&D. Traditionally, it relied on the suppliers of T\&D equipment, who have been spending between 2 and 3 percent of their sales on R\&D. However, there are signs of change in an era that emphasizes deregulation and renewable, dispersed generating sources. These forces increase pressure to improve an aging network - to opt in new sources of power, reduce blackouts, conserve energy, improve connectivity, limit losses, and smooth out peaks and valleys of usage. The "smart grid" concept encompasses these goals by incorporating various devices such as meters, sensors, and other control devices. A system of variable pricing policies that allows prices to reflect costs by season and time of day will have to accompany the technical changes.

Various public and private bodies are hard at work on new protocols and products. At the federal level, two major agencies - the Federal Energy Regulatory Commission and the National Institute of Standards and Technology-joined with equipment vendors to lay the groundwork for interoperability of regional systems as well as intersystem communications. Operators will have a full or wide-area view of the system; coordinate generators, transmitters, and users; and maintain secure lines. At the local level, a pilot project is under way by Xcel Energy in Boulder, CO that offers efficiency and conservation options, starting with 15,000 smart meters and over 100 miles of cable for broadband communication over power lines. The smart grid idea offers many potential entry points for $T \& D$ product and service vendors. However, it is possible that more spending on sensors and controls could come at the expense of traditional T\&D equipment, such as transformers and switchgear.

Beyond the smart grid, there are other specific technological advances. EPRI currently conducts programs on underground and overhead transmission, as well as on distribution, with the goal of improved reliability and security of both systems and equipment. One example is a robot that is designed to traverse and inspect 80 miles of transmission line for high-risk vegetation encroachment. The major equipment companies, such as General Electric, Eaton, Schneider Electric, and Siemens, are developing improved switchgear, such as arc-fault circuit interrupters. Hexaformer of Sweden is now producing transformers that offer different core shapes featuring less weight and smaller load losses. A public-private cooperative venture is looking at high temperature superconducting materials for use in advanced transformers.

\section{T\&D Equipment Supply-The Product Lines}

$\mathrm{T} \& \mathrm{D}$ equipment is designed to assist both providers and users of electric power with smooth system operation, protection, and measurement. Such equipment is the hardware that links generating plants and retail uses by farms, factories, offices, and households. Actual linkage occurs via high-voltage (138 kv and higher) transmission lines and low-voltage (under $50 \mathrm{kv}$ ) distribution lines. There are four categories of T\&D equipment: switchgear, transformers, pole and line hardware, and meters. Supply of these four product categories is shown in Table 3 . The first two groups are dominant in terms of revenues accounting for 51 and 38 percent of the total in 2008, and these shares are not expected to change in the current five-year span to 2013.

\section{Switchgear}

This term refers to a variety of circuit breakers, relays, fuses, and ducts designed to control and direct the flow of electric power to industrial, commercial, and residential users. Such control must assist uninterrupted power flow, but must also provide instant protection against disturbances such as abrupt changes in voltage, current, frequency, and so on. Detecting and isolating problems assure safety at user locations and for the network system as a whole. Switchgear can be found in outdoor locations, such as utility substations, and indoors in factory or office building control rooms. Switchgear is often coupled with other major devices such as transformers as well as with meters and communication 


\begin{tabular}{|c|c|c|c|c|c|}
\hline \multirow[b]{2}{*}{ Item } & \multirow[b]{2}{*}{2003} & \multirow[b]{2}{*}{2008} & \multirow[b]{2}{*}{2013} & \multicolumn{2}{|c|}{ Annual growth } \\
\hline & & & & $08 / 03$ & $13 / 08$ \\
\hline Nonres. Fixed Investment (billion \$) & 1078 & 1553 & 1730 & $7.6 \%$ & $2.2 \%$ \\
\hline$\$$ elec $T \& D$ eqp $/ 000$ \$invest. & 13.4 & 13.4 & 13.6 & - & - \\
\hline Elec. Power T\&D Eqp. Supply & 14,472 & 20,750 & 23,550 & 7.5 & 2.6 \\
\hline Switchgear & 8,169 & 10,550 & 11,950 & 5.2 & 2.5 \\
\hline Transformers & 4,768 & 7,890 & 8,850 & 10.6 & 2.3 \\
\hline Pole \& line hardware & 795 & 1,200 & 1,350 & 8.6 & 2.4 \\
\hline Meters & 740 & 1,110 & 1,400 & 8.4 & 4.8 \\
\hline Net exports & (787) & $(2,400)$ & $(3,550)$ & - & - \\
\hline Elec. Power T\&D Eqp. Shipmts. & 13,685 & 18,350 & 20,000 & 6.0 & 1.7 \\
\hline
\end{tabular}

equipment to achieve "intelligent control" of energy management.

Low voltage switchgear, rated at 600 volts or less, is often found in commercial and residential applications. It consists of switches, switchboards, panels, and circuit breakers. This subcategory accounted for about one-third of the total $\$ 10.5$ billion shipped in 2008. Another third wastaken by metalclad switchgear, metal-enclosed fuses, and molded case circuit breakers primarily used by utilities and industrial firms. The final subgroup consists of a mix of power circuit breakers, fuses, ducts, and relays. Low cost overseas producers compete intensely in many product lines.

\section{Transformers}

As the name implies, these units "transform power"-specifically, they provide a step-up or stepdown for voltage. The key application is to increase voltage before transmitting electric power over long distances (up to $345 \mathrm{kv}$ or even $765 \mathrm{kv}$ ) and then to decrease this high voltage for use in distribution at the retail or household level. Thus, generating plants can be located far away from population centers, and power can be transmitted using towers and wires/cables. During 2003-2008 transformer sales grew at an annual rate of 10.6 percent, reflecting in part the rapid increases in the prices of raw materials used, such as electrical steel, copper, and aluminum.

There are significant differences in the design and function between large power transformers and smaller, distribution transformers. The former are oilcooled, equipped with monitors, and designed for long life; often they are custom-made for a specific application. The latter are compact, may be nonventilated or air-cooled, and are mass-produced. Power transformers (500 kva-mva) accounted for 40 percent of the $\$ 7.9$ billion total in 2008 , distribution transformers at 28 percent, with specialty and other transformers plus parts taking 22 percent. These figures are not expected to shift much. Makers of large units experiment with new materials and core shapes, but buyers object to higher prices that can be 20 percent more. Further, new designs require testing for durability and regulatory compliance.

\section{Pole and line hardware}

This category consists of a wide variety of insulators, arresters, connectors, clamps, anchors, and fittings used for T\&D between the generating plants and the final end users. Most of the hardware is used overhead but underground distribution is expanding in densely populated areas. Much of the hardware is made of steel, except for insulators. In the past, insulators have been formed from ceramics; now they combine a ceramic core for strength and polymer for reduced weight and improved electrical performance. The category as a whole is supported more by replacement requirements than new market opportunities. About 5 percent of the more than 80 million wooden and steel lattice utility 
pole structures is either replaced or have components upgraded annually, thereby generating demand for anchors and other line hardware.

Of the $\$ 1.2$ billion worth of pole and line hardware shipped in 2008, just over one-half consisted of T\&D and communication hardware, followed by insulators at 27 percent, with connectors, anchors, and other line hardware taking up the remaining 21 percent. While the sector may benefit from the building of new, major transmission lines, plus linkage with renewable sources of power, it will be adversely affected by growth in underground systems needing no pole hardware. The growth in more localized, distributed generation will also pose a risk to makers of pole and line hardware as small-scale production of power near end users makes the need far less for any further build-up or replacement of T\&D facilities.

\section{Electricity meters}

This category consists of various kinds of meters that record electric power usage by clients, measured in kilowatt-hours; such readings establish a billing cycle. But meters can also be used to record instantaneous demand (kilowatts) or maximum use over some interval; this can aid users and producers with energy savings. Sale of meters was traditionally driven by new construction and the replacement of old meters at regular intervals. But new housing and other new construction have slowed down, and the steady replacement rate is upset by growth in automated meter reading, net metering programs, and smart meters. As of 2010, all but six states had some form of net metering that allows customers to sell power that they generate in excess of their own needs to the grid. Smart meters offer advanced electronics, twoway communication, and pricing options for users.

The most widely used meter is the traditional alternating current (AC) watt-hour unit that has changed little since its invention by Otto Bathory in 1889; but it now comes as an analog or digital device. Of the $\$ 1.1$ billion total meter shipments in 2008, AC watt-hour meters took 35 percent, followed by demand meters that measure watts at any given time at 26, other electric meters at 27 , and parts and accessories at 12 percent. While meters constitute the smallest of the four major categories of T\&D equipment, the group shows the fastest growth rate at almost 5 percent per annum between 2008 and 2013. Smart meters, while they often cost twice the traditional ones, will form an important part of the developing "smart grid" and allow providers of electricity net metering, time-of-day metering, and automated reading. Wind farms also use smart meters to measure generation.

\section{T\&D Equipment Demand- Markets or End-Users}

The two largest markets for T\&D equipment are electric utilities and industrial plants, followed by the commercial, residential, and governmentinstitutional sectors. Details for all five are shown in Table 4 for the 2003-2013 period. In 2008, utilities accounted for 48 and the industrial sector for 33 percent; the remaining three sectors came in at 8, 7, and 4 percent, respectively. All five markets will experience much slower growth rates during 2008-2013 than they recorded for 2003-2008. Annual growth rates will be in the 2 to 4 percent range due to slow growth in the economy in general and nonresidential fixed investment in particular. In comparison, therefore, the future of $T \& D$ equipment sales in the five markets is seen as relatively bright.

\section{Electric utilities}

The primary concern in this sector is facilitating electricity flow and protecting equipment all the way between generating plants and end users. Thus, utilities must purchase from all four product families; of the $\$ 9.9$ billion spent in 2008 , they dispensed $\$ 4.4$ billion for transformers and $\$ 3.7$ billion for switchgear, with the remaining $\$ 1.8$ billion for pole/line hardware and meters. Specifically, power and distribution transformers, circuit breakers and other switchgear were high on their shopping lists in the past, along with line hardware.

Responding, albeit slowly, to competition from NUGs and regulatory pressure, the utilities embarked on replacing aging equipment. They became more confident about their spending as state and federal rules eased and as cost-recovery schemes were approved. There have been some large mergers among utilities, and revenue streams have improved. On balance, emergence of renewable sources of energy and distributed generation are viewed as a plus for T\&D sales in this sector. The equipment mix bought by utilities is slowly altering. Products 


\begin{tabular}{|c|c|c|c|c|c|}
\hline \multirow[b]{2}{*}{ Item } & \multirow[b]{2}{*}{2003} & \multirow[b]{2}{*}{2008} & \multirow[b]{2}{*}{2013} & \multicolumn{2}{|c|}{ Annual growth } \\
\hline & & & & $08 / 03$ & $13 / 08$ \\
\hline Nonres. Fixed Investment (billion \$) & 1,078 & 1,553 & 1,730 & $7.6 \%$ & $2.2 \%$ \\
\hline \$ elec T\&D eqp/000\$invest. & 13.4 & 13.4 & 13.6 & - & - \\
\hline Elec. Power T\&D Eqp. Demand & 14,472 & 20,750 & 23,550 & 7.5 & 2.6 \\
\hline Electric utilities & 6,474 & 9,900 & 10,900 & 8.9 & 1.9 \\
\hline Ind'l \& nonutil. gen. & 4,757 & 6,870 & 8,050 & 7.6 & 3.2 \\
\hline Commercial market & 1,396 & 1,735 & 1,945 & 4.4 & 2.3 \\
\hline Residential market & 1,235 & 1,475 & 1,730 & 3.6 & 3.2 \\
\hline Gov'ts/Instit'ns & 610 & 770 & 925 & 4.8 & 3.7 \\
\hline Net exports & (787) & $(2,400)$ & $(3,550)$ & - & - \\
\hline Elec. Power T\&D Eqp. Shipmts. & 13,685 & 18,350 & 20,000 & 6.0 & 1.7 \\
\hline
\end{tabular}

with strong potential are electronic switches, metal-clad switchgear, and smart meters.

\section{Industrial users and NUGs}

This is a dual market: in manufacturing plants, T\&D equipment is used for operating, protecting, and monitoring expensive machinery; for NUGs purchase of $\mathrm{T} \& \mathrm{D}$ products assists with the production and distribution of electric power. In addition, deregulation of electric power generation spurred trends toward cogeneration and bulk power purchases by large industrial users; this enhanced the demand for T\&D goods in the sector. In contrast to the electric utility sector, switchgear dominates transformers with the former at $\$ 4.0$ billion and the latter at $\$ 2.6$ billion in 2008, with line hardware plus meters at only $\$ 0.2$ billion in sales. Advanced switchgear, specifically power circuit breakers, are favored by industrial users as they wish to protect their automated process lines from power surges, fluctuations, and outages.

\section{Commercial sector}

Building owners, office managers, and store operators make wide use of computer systems, security arrangements, and inventory stockings, all of which must be protected against any abrupt - or even minor-changes in their power supplies. Airconditioners and other indoor climate controls contribute also to the increasing use of electricity per square foot of office or retail space; our estimate is a rise from 28.2 to $32.6 \mathrm{kw}-\mathrm{hr} /$ sq.ft. from 2003 to 2013. Commercial space in the United States is increasing slightly, year after year, despite smaller cubicles and off-site work.

In Table 5, we show details for this sector by major product lines and by specific commercial end-users. Switchgear overshadows the purchase of transformers. Circuit breakers replaced fuses as they offer better protection and compatibility with advanced power distribution. Distribution transformers are still widely in use. Utilities are now shifting the purchase of meters to builders or building owners.

The three subgroups in this sector with the largest volume of T\&D equipment purchases are mercantile, office, and warehouse entities. However, during the current span of 2008-2013, the fastest growing sectors will be lodging and food sales/service establishments, in short, the hospitality segment. Some of these operations will be using solar panels in the future and hence will opt for net metering programs.

\section{Residential sector}

While the resident population and the number of households are rising in the United States, housing completions are projected to decline slightly from 1.8. million in 2003 to 1.7 million units in 2013. Residential floor space will show a small rise from 205 billion in 2003 to about 237 

Table 5. Demand in One Specific Sector: Commercial End-Users' Purchase of Electric Power Transmission \& Distribution (T\&D) Equipment, United States, 2003-2013
(million dollars except as noted)

\begin{tabular}{|c|c|c|c|c|c|}
\hline \multirow[b]{2}{*}{ Item } & \multirow[b]{2}{*}{2003} & \multirow[b]{2}{*}{2008} & \multirow[b]{2}{*}{2013} & \multicolumn{2}{|c|}{ Annual growth } \\
\hline & & & & $08 / 03$ & $13 / 08$ \\
\hline Comm Mkt Elec Pwr Use (billion kwhr) & 1206 & 1375 & 1475 & $2.7 \%$ & $1.4 \%$ \\
\hline$\$$ elec $T \& D$ eqp $/ 000 k w h r$ & 1.16 & 1.26 & 1.32 & - & - \\
\hline Commercial Market & 1396 & 1735 & 1945 & 4.4 & 2.3 \\
\hline \multicolumn{6}{|l|}{ By product line } \\
\hline Switchgear & 1026 & 1200 & 1340 & 3.2 & 2.2 \\
\hline Transformers & 338 & 465 & 515 & 6.6 & 2.0 \\
\hline Hardware \& Meters & 32 & 70 & 90 & 16.9 & 5.1 \\
\hline \multicolumn{6}{|l|}{ By commercial sub-sector } \\
\hline Mercantile \& service & 405 & 495 & 550 & 4.1 & 2.1 \\
\hline Office & 399 & 490 & 540 & 4.2 & 2.0 \\
\hline Lodging & 167 & 235 & 275 & 7.1 & 3.2 \\
\hline Food sales \& service & 95 & 120 & 140 & 4.8 & 2.0 \\
\hline Warehouse \& other & 330 & 395 & 440 & 3.6 & 2.2 \\
\hline Comm'l Market as \% of Total Mkt & $9.6 \%$ & $8.4 \%$ & $8.3 \%$ & - & - \\
\hline Total Elec. Pwr. T\&D Eqp. Mkt. & 14,472 & 20,750 & 23,550 & 7.5 & 2.6 \\
\hline
\end{tabular}

Source: The Freedonia Group [2009].

billion square feet in 2013. Sales of T\&D equipment in this sector will continue to grow slightly above 3 percent per year. This growth is aided by the use of more electric and electronic devices (ranging from entertainment to security) in homes. Building codes are requiring higher levels of protection in new buildings, even to the specification of devices, such as the use of arcfault circuit interrupters. The use of solar panels or other power generation should benefit the market for smart meters and net metering programs.

\section{Governments and institutions}

While this sector is the smallest, it is likely to grow the fastest in the current five-year span, though still under 4 percent per year. Factors affecting this sector is spending on infrastructure, both new construction and repair or upgrade of existing facilities. While some urban districts shut down old schools and other buildings, suburbs are seeing new units, such as recreation centers and neighborhood clinics. There will be more switchgear than transformer sales in this sector, with hardware and meters accounting for less than 10 percent of the total. High-intensity discharge ballasts (a form of specialty transformer) are likely to record higher sales - in this as well as in the commercial and residential sectors - as they gain against fluorescent systems in lighting up dark spaces.

\section{The World Market, Investment, and U.S. Trade}

The United States is the single largest market for T\&D equipment, but its share is eroding as industrialization takes place around the globe. World demand for T\&D equipment is estimated at about $\$ 68$ billion in 2003 with projection to $\$ 142.5$ billion for 2013. The U.S. share should decline from 21 to 16.5 percent in that span. Both the North American and the West European market will grow below the world rate of 4.5 percent per annum. The fastest growth is slated for the Asia-Pacific region, led by China where sales of T\&D units almost tripled between 2003 and 2008 .

The electric power T\&D equipment industry has become increasingly international in scope during the past two decades, with a rise in the volume of trade, the amount of direct foreign investment, and the number of collaborative ventures. In terms of product lines, advanced switchgear and high-voltage transformers are especially in demand in almost all regions. In 
terms of major end-use markets, the industrial and the commercial sectors show the strongest gains. Utilities are facing deregulation in several nations and are experiencing competition from the independent power providers and the NUGs.

Attracted by the large size of the U.S. market, European firms established production facilities here. Among these entering were: ABB (Switzerland), Schneider Electric, Areva, Carbone Lorraine (France), Siemens (Germany), and Philips (Netherlands). Hammond Power (Canada) and Mitsubishi Electric (Japan) also operate in United States. In turn, U.S. firms have gone abroad, especially to Mexico, where Actuant, Basler Electric, Carling Technologies, Cooper Industries, and General Electric operate sole or joint venture facilities with Mexican partners (GE is linked to Prolec via Xignux). Of course, the U.S. firms are investing well beyond Mexico and conduct much trade.

The U.S. foreign trade situation in T\&D equipment shows an ongoing deficit between 2003 and 2013. Exports as a percent of shipments are projected to move from 18.2 percent in 2003 to 20.7 percent in 2013 . Imports as a percent of demand are seen as rising from 22.7 percent to about 32.7 percent during the same 10-year span. The result is a $\$ 2.4$ billion deficit in 2008 (for details, see Table 3). Import growth is now driven by the commodity nature of lowend products such as fuses and molded case circuit breakers from low-cost manufacturers in Latin America and Asia-Pacific. However, Western nations are major markets for more sophisticated devices.

Of the $\$ 6.1$ billion T\&D equipment imported in 2008,
Mexico contributed 39 percent. Next came Western Europe at 18, China at 11, and Canada at 10 percent. On the export front, U.S. exports of T\&D equipment recorded $\$ 3.7$ billion worth of shipments to these destinations: Mexico at 22.5, Canada at 18.4, Western Europe 12.3, and Dominican Republic at 12.8 percent of the total in 2008 .

\section{Industry Structure, Conduct, and Performance}

The T\&D equipment field is a part of the larger electric power equipment industry. The latter includes a wide variety of equipment used at power plants such as a wide range of turbines and generators; also included in the broader category are poles, transmission towers, wire, and cable. But these are beyond the scope of this article and the far longer report on which it is based. For many of the leading firms in the broader arena, T\&D equipment represents less than half their volume; the case for the smaller companies is just the opposite.

The T\&D equipment sector is relatively mature and exhibits relatively low growth, plus limited potential for product innovation. Indeed, the conservative nature of the industry, and the long lifespan of many products delays the introduction of radical technologies. Still, many leading firms have increased their capital spending during 2005-2009. The cyclical nature of the industry favors those that can make substantial investment. At the same time, cooperative agreements have been forged, and the pace of mergers/acquisitions has risen in the past five years as firms plan to capture new ideas from partners, broaden their product lines, and expand into new foreign markets. Competition is usually on the basis of product differentiation for high-end goods and aggressive pricing for lowend, commodity-like devices.

Our estimate is that there are several hundred-possibly up to 500 - companies active in the T\&D industry in the United States, a good mix of domestic and foreign firms. Firms range from small ones operating in a given region only, say the Southwest, to large multinationals with diverse product lines across the United States and abroad. There is some consolidation at the top, with six firms accounting for 40 percent of the total market in 2008. They are General Electric, Eaton, and Cooper Industries from the United States and ABB, Siemens, and Schneider Electric from Western Europe. There is a strong, second tier of firms with at least $\$ 200$ million of sales: Howard Industries, Hubbell, Itron, Powell Industries, S\&C Electric, and SPX from United States, Areva and Elster from Western Europe. Powerful Chinese companies may appear soon on this list.

\section{Leading firms and brands}

Many of the large companies in the industry operate through a division that was acquired earlier and has maintained its brand identity. Some small firms, due to longevity, are also able to emphasize their brands. In 2008, ABB acquired Kuhlman Electric, a privately held U.S. maker of transformers and parts; it did sell some of the Kuhlman product line later to Power Partners. Siemens still uses the Osram brand for its high-intensity discharge ballasts and the related lighting products. GE Energy has 
a joint venture for transformer production with Xignux of Mexico; the operation is known as Prolec GE Internacional. Schneider Electric acquired Square D many years ago, a respected firm in United States. In a similar fashion, Eaton features the Cutler-Hammer and Heinemann brands, while Cooper Industries has the former Crouse-Hinds product line. Smaller firms with visibility include Buswell Energy, Hexaformer, and Preformed Line Products. The Waukesha Electric division of SPX is linked with Philips in development of superconducting transformers under the auspices of the U.S. Department of Energy.

\section{Marketing activities}

The marketing task for firms operating in this field is bound up with the specific category of product line and the markets served. For example, very large transformers are manufactured and then sold almost exclusively to large electric utilities. In contrast, millions of molded case circuit breakers are sold annually to a wide variety of users in all four major markets. The complex, high-value units are marketed by the elite sales forces of large firms and are often subject to high-level negotiations. In a similar fashion, the sales force would be involved in submitting bids on advertised contracts, usually to large, public entities that set their own product specifications and benchmarks. Reputation, experience, and word-of-mouth testimonials all come into play in such vendor-buyer relationships.

In the case of mass-produced, near-commodity products-such as fuses, simple circuit breakers, distribution transformers - large chain and/ or small independent distributors are much more likely to be involved. Their inventory holdings will be relatively high and feature variants of the same product from several suppliers. As noted earlier, price plays an important role in the sale of such devices. At times, consulting engineering firms constitute yet another channel through which the commodity type products are marketed. This is the case when consultants take a role not just in design, but also the construction of a large project, integrating many components and subsystems. In some cases, specialized distribution channels arise, such as rural electric utilities have often formed cooperative ventures. Last but not least, the Internet/Web plays an increasingly significant role in marketing, as both large and small firms display product lines, technical information, manuals, and even prices and order forms on their websites. Consolidators have come into play too, such as btbplaza.com, which had more than 240 transformer factories in its database by 2009 and allowed potential customers to contact the vendors directly.

\section{Collaboration and merger/ acquisition}

Several types of cooperative agreements have been put into place by large, medium and small firms in the T\&D market. Examples are licensing, joint ventures, $\mathrm{R} \& \mathrm{D} /$ technology, and marketing agreements. The rationale in such decisions can range from cost savings to sharing ideas, from expansion into foreign markets to sharing liability burden. A fundamental goal is to strengthen relationships with existing and potential customers. Examples are ABB's supply, distribution, and licensing arrangements with TVA, Power Partners, and Arteche Group; Eaton and Caterpillar forming Intelligent Switchgear, a joint venture; and General Electric forming Prolec with Xignux.

The T\&D equipment industry has seen a definite restructuring and consolidation in the past decade, with several mergers and acquisitions taking place. Notable was Itron's acquisition of Actaris, combining two leading makers of meters on the two sides of the Atlantic. ABB acquired Kuhlman Electric from the Carlyle Group, thereby strengthening its position in the U.S. market. Hammond Power of Canada purchased Delta Transformer; Littelfuse acquired Shock Block and Startco Engineering; and Thomas \& Betts bought both Power Solutions and Joslyn Hi-Voltage from Danaher. In some cases, the acquisition is just for a specific product, such as Carbone Lorraine's Ferraz Shawmut purchasing the medium voltage fuse business of General Electric.

\section{REFERENCES}

Deneen, Michael A., and Andrew C. Gross. 2006. "The Global Market for Power Tools." Business Economics, 41(3): 66-73.

The Freedonia Group, 2009. "Electric Power Transmission \& Distribution Equipment," Industry Study \#2503.

U.S. Energy Information Administration, 2011. "Annual Energy Outlook 2011," Report Number: DOE/EIA-0383(2011).

Vastag, Brian. 2011. "White House Pushes Policies to Upgrade Nation's Aging Electrical Network." Washington Post (June 13). 